\title{
The Regulation on Matrimonial Property and Its Operation in Succession Cases Its Interaction with the Succession Regulation and Its Impact on Non-participating Member States
}

\begin{abstract}
The Regulations on Matrimonial Property (No 2016/1103) and on the Property Consequences of Registered Partnerships (No 2016/1104) are new important pieces in the "puzzle" of European private international law. This article particularly focuses on the relationship between the Matrimonial Property Regulations and the Succession Regulation, two instruments which will often be applied in parallel because of the close connection between the two areas they govern. The author examines in particular the scope of those instruments as well as their interaction with respect to jurisdiction and applicable law. At the same time, an attempt is also made to assess the position of Poland and of those other Member States that are bound by the Succession Regulation, but not by the Matrimonial Property Regulation.
\end{abstract}

Keywords: matrimonial property — registered partnerships — private international law — succession — EU Regulations — family law — non-participating Member States

a) Prof., l'Université de Lausanne (Unil), Directeur du Centre de droit comparé, européen et international (CDCEI), Co-directeur du LL.M in International Business Law. 


\section{Introduction}

The Regulations on Matrimonial Property (No 2016/1103) and on the Property Consequences of Registered Partnerships (No 2016/1104) are new important pieces in the "puzzle "of European private international law. They cover wide and important fields of family law, thus completing the Brussels IIbis Regulation (which will be replaced in some years by the Brussels IIter Regulation ${ }^{1}$ ), the Rome III Regulation, the Maintenance Regulation, and the Succession Regulation.

Since the links between the topics regulated by these instruments are very tight, it is important that they are now all regulated at the European level. This enhances consistency, at least with respect to the origin of the sources of the applicable rules, the way they are interpreted, their scope and their interaction. Thus, the material scope of application of all regulations mentioned above is designed in a way that avoids overlapping between those instruments, while such coordination does not necessarily exist between European and national PIL rules. A certain amount of coherence is also ensured with respect to the basic approaches followed by the harmonised rules: just to provide an simple example, all European PIL regulations use habitual residence as the main connecting factor, while several Member States still give priority to nationality in their national PIL systems.

Unfortunately, the benefits of harmonisation are restrained by the fact that not all of EU instruments are applicable in all Member States. The Regulations on Matrimonial Property and Registered Partnership have been adopted by way of enhanced cooperation, and are therefore applicable in only 18 Member States ${ }^{2}$. A similar limitation applies to the Rome III Regulation: however, the 17 participating Member States ${ }^{3}$ are only partially the same that adopted the 2016 Regulations. The Succession Regulation is applicable in 25 Member States, with the exception of

${ }^{1}$ As from 1 August 2022 Brussels II bis will be replaced by the Council Regulation (EU) 2019/1111 of 25 June 2019 on jurisdiction, the recognition and enforcement of decisions in matrimonial matters and the matters of parental responsibility, and on international child abduction (recast), OJ L 178, 2.7.2019, pp. 1-115.

2 Austria, Belgium, Bulgaria, Croatia, Cyprus, Estonia, Finland, France, Germany, Greece, Italy, Luxemburg, Malta, the Netherlands, Portugal, the Czech Republic, Slovenia, Spain, and Sweden: see Recital 11.

${ }^{3}$ Austria, Belgium, Bulgaria, Estonia, France, Germany, Greece, Hungary, Italy, Latvia, Lithuania, Luxemburg, Malta, Portugal, Romania, Slovenia, and Spain. Cf. https://e-justice.europa.eu/content_law_applicable_to_divorce_and_legal_separation356-maximize-en.do (accessed: 31.08.2020). 
Denmark and Ireland. The Maintenance Regulation is applicable in all Member States ${ }^{4}$, however the reference it entails to conflict of law rules of the 2007 Hague Protocol does not apply in Denmark and Ireland. Finally, the Brussels IIbis Regulation is applicable in all Member States, however once again with the exception of Denmark.

An additional source of confusion is that not all of these instruments are applicable to the same family relationships. The Brussels IIbis Regulation and the Rome III Regulation only concern married couples and do not cover registered partnerships. Moreover, their applicability to samesex marriages is debatable ${ }^{5}$, and this question was not clarified by the 2019 recast. The applicability to registered partnerships of the Maintenance Regulation ${ }^{6}$ and of the 2007 Hague Protocol $^{7}$ depends on their characterisation as family relationships, which may vary from one Member State to the other. As for the Matrimonial Property Regulation, it refers, for the definition of marriages, to the law of the Member States ${ }^{8}$.

In this short paper, I will focus, on the one hand, on the relationship between the Succession Regulation and the Matrimonial Property Regulation. Because of the connection between these two areas, these two instruments will often be applied in parallel in those Member States, in which they are both applicable. By contrast, I will not address the interactions with the other, already mentioned regulations.

On the other hand, I will also try to determine - always in the relation with the succession of one of the spouses - the impact of the Matrimonial Property Regulation on non-participating Member States. In this respect, it is important to highlight that, while all Member States

${ }^{4}$ In Denmark, by virtue of an Agreement of 19 October 2005.

${ }^{5}$ W. Pintens, in: U. Magnus, P. Mankowski: Brussels IIbis Regulation. Munich 2012, Art. 1er n ${ }^{\circ}$ 21.; Th. Rauscher: EuZPR-EuIPR Europäisches Zivilprozess- und Kollisionsrecht - Kommentar, vol. IV, Art. 1 Brüssel IIa-VO, nº 6 à 8; S. Corneloup, in: Droit européen du divorce. Ed. S. Cor neloup. Paris, 2013, p. 503; P. Ha m mje: 'Mariage pour tous' et droit international privé. "Rev. crit. DIP”, 2013, p. 773.

${ }^{6}$ See M. Andrae, in: Th. Rauscher: EuZPR-EuIPR Europäisches Zivilprozessund Kollisionsrecht - Kommentar, vol. IV, Art. 1 EG-UntVO, $\mathrm{n}^{\circ} 5$.

7 See A. Bonomi: Explanatory Report on the Hague Protocol of 23 November 2007 on the Law Applicable to Maintenance Obligations, The Hague 2009.

${ }^{8}$ See Recital 17. In our understanding, this implies a reference to the law of the forum, including its private international law system: see A. Bonomi: Fragen des Allgemeinen Teils: Qualifikation, Vorfrage, Renvoi und ordre public. In: Die Europäischen Güterrechtsverordnungen. Eds. A. Dutta, J. Weber. Beck, 2017, n 45 ss, p. 131 s. However, this is controversial: see D. Coester-Waltjen: Connecting Factors to Determine the Law Applicable to Matrimonial Property Regimes. "YPIL", 2017/2018, p. 203 (law of the forum without the conflict of law rules); A. Dutta: Beyond Husband and Wife New Couple Regimes and the European Matrimonial Property Regulations. "YPIL", 2017/2018, p. 149 (law of the country where the marriage was celebrated). 
bound by the Matrimonial Property Regulation are also bound by the Succession Regulation, the opposite is not true. Poland and several other Member States, which are bound by the Succession Regulation, are not participating in the enhanced cooperation that allowed the adoption of the Matrimonial Property Regulation?.

\section{The notion of "Member State" and the impact of the Matrimonial Property Regulation on non-participating Member States}

It is important to clarify from the outset the meaning of the term "Member State" as used in the Matrimonial Property Regulations, and the impact of this instrument on non-participating Member States, if such occurs.

Although the Matrimonial Property Regulation does not clearly provide for it, non-participating Member States should be regarded, for the purpose of this instrument, as non-Member States. This was already the case under the Succession Regulation ${ }^{10}$, and there can be no doubt that this interpretation is also appropriate here. Indeed, only this reading is compatible with the provision of the Treaty on the European Union concerning enhanced cooperation: indeed, non-participating Member States are not bound by the provisions of the Regulation ${ }^{11}$. This is true not only with respect to procedural law provisions, such as rules on jurisdiction, and on recognition and enforcement of decisions, authentic instruments and judicial settlements, but also with respect to conflict-of-laws rules.

While only participating Member States are bound by the Regulation, this instrument has a significant impact on non-participating Member States and third States - as it is also the case of the Succession Regulation.

Admittedly, certain rules of the Matrimonial Property Regulation are only applicable inter partes, that is, in the relationships among partici-

9 This is the case of Croatia, Hungary, Latvia, Lithuania, Romania, and Slovakia.

${ }^{10}$ A. Bonomi, P. Wautelet: Le droit européen des successions : commentaire du Rè-

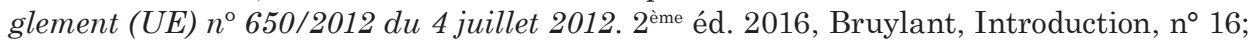
A. Davì: Introduction. In: A.-L. Calvo Caravaca, A. Davì, H.-P. Mansel: The EU Succession Regulation. Cambridge, 2016, n 13, p. 17 et s.

${ }_{11}$ Under Article 20(4) of the Treaty on European Union, "[a]cts adopted in the framework of enhanced cooperation shall bind only participating Member States [...]". 
pating Member States. This is the case of the rules on foreign decisions, authentic instruments and judicial settlements: indeed, it follows from the notion of "mutual recognition", that decisions originating from nonparticipating Member States cannot benefit from the provisions on recognition and enforcement under the Regulation, and the same is true for authentic instruments and judicial settlements ${ }^{12}$. In this area, Member States will continue to apply their national rules. The same is probably also true with respect to lis pendens and related actions, in the absence of provisions equivalent to those of Articles 33 and 34 of the Brussels Ibis Regulation ${ }^{13}$.

By contrast, the rules on jurisdiction and the conflict of rules included in the Regulation are applicable in the participating Member States even when the internationality of the situation results from contacts with non-participating Member States or third States. One may say that such rules have an erga omnes dimension.

This is clearly provided for with respect to conflict of laws rules by Article 20 ("universal application"). As stated in this provision, "[t]he law designated as applicable under this Regulation shall be applied whether or not it is the law of a Member State", a language which mirrors that included in all other EU regulations on the applicable law. As a consequence, most provisions of Chapter III refer to the law of a "State", which obviously includes both Member States and third States.

Only Articles 23 and 25 of the Regulation, concerning the formal validity of choice of law agreements and matrimonial agreements, seem to reflect a different approach. Besides some minimum uniform formal requirements (a document "in writing, dated and signed"), these provisions also refer, in paragraph 2, to additional formalities, as provided under the law of the "Member State" where the spouses (or one of them) have their habitual residence. By contrast, these provisions do not refer to formalities provided by the law of a non-Member State. Since the rationale of such distinction is far from clear, it is open to discussion whether the reference to the law of a "Member State" should include all Member States or only participating Member States: in either case, the limitation is highly objectionable ${ }^{14}$.

While no specific provision on "universal application" is included in Chapter II, rules on jurisdiction are also applicable erga omnes, that is,

${ }^{12}$ With respect to the Succession Regulation see A. Bonomi, P. Wautelet: Le droit européen des successions..., Introduction, $\mathrm{n}^{\circ} 16$.

${ }^{13}$ See infra, section VI.

${ }^{14}$ Indeed, if the application of the formal requirement of the State of the habitual residence aims at protecting the spouses' legitimate expectations, there is no reason for excluding formalities provided under the law of a third State. 
even in the absence of any relationship to another Member State. Indeed, as the CJEU ruled in Owusu, the internationality of the situation, which is required for the EU jurisdictional rules to apply, can also result from connection to a non-Member State ${ }^{15}$. This is true $a$ fortiori for the Matrimonial Property Regulation, where the jurisdictional rules are exhaustively listed, thus leaving no room for the application of national jurisdictional rules of the Member States ${ }^{16}$. Therefore, such rules are not only applicable in the relationship to other participating Member States, but also in situations connected to non-participating Member States (such as Poland) or non-Member States.

\section{The issues regulated by the Matrimonial Property Regulation and by the Succession Regulation}

a) Private International Law issues

The Matrimonial Property Regulation governs issues that are very similar to that of the Succession Regulation. Both instruments cover all main private international law questions: jurisdiction, applicable law, recognition and enforcement of decisions, acceptance and enforcement of authentic instruments, and enforcement of judicial settlements. By contrast, they do not affect substantive law, which remains under the exclusive competence of the Member States.

b) No rules on the European Certificates of Succession

Obviously, the Matrimonial Property Regulation does not provide for an instrument comparable with the European Certificate of Succession (hereafter: "ECS"). What is more surprising, and somewhat disappointing, it does not include any specific provision to complement the rules on the ECS of the Succession Regulation.

As is well known, pursuant to Article 68(h) of the Succession Regulation, the ECS also includes "information concerning a marriage contract

${ }^{15}$ CJEU, 1 May 2005, Owusu, in case C-281/02, ECLI:EU:C:2005:120, para. 26: "The involvement of a Contracting State and a non-Contracting State, for example because the claimant and one defendant are domiciled in the first State and the events at issue occurred in the second, would also make the legal relationship at issue international in nature".

${ }^{16}$ See Recital 40. 
entered into by the deceased or, if applicable, a contract entered into by the deceased in the context of a relationship deemed by the law applicable to such a relationship to have comparable effects to marriage, and information concerning the matrimonial property regime or equivalent property regime" (emphasis added). However, the effect of such information is quite limited. Indeed, under Article 69(2), the effects of the ECS, and in particular its evidentiary effects and the presumption of accuracy that attaches to it, only concern "elements which have been established under the law applicable to the succession or under any other law applicable to specific elements". Recital 71 clarifies this by stating that "the evidentiary effect of the Certificate should not extend to elements which are not governed by this Regulation, such as questions of affiliation or the question whether or not a particular asset belonged to the deceased" (emphasis added).

According to a wide-spread interpretation ${ }^{17}$ — which was shared by A-G Szpunar in his opinion in the Mahnkopf case ${ }^{18}$ and confirmed, at least incidentally, by the Court in its decision in the same case ${ }^{19}-$ this means that the effects of the ECS do not extend to the information it contains concerning the marriage contract and/or the matrimonial property regime. The main reason for this is that - at the time of the adoption of the Succession Regulation - such information had to be determined under the law designated by the national choice of rules in force in the Member State of the forum, as opposed to harmonised conflict of law rules. It followed that information concerning matrimonial property included in the ECS might differ depending on the Member State of issuing: therefore, it could not benefit of the evidentiary effects and the presumptions attached to the $\mathrm{ECS}^{20}$.

After the entry into force of the Matrimonial Property Regulation with its harmonised conflict of laws rules, however, this reasoning is not applicable anymore as far as participating Member States are concerned. Therefore, the effects of the ECS should now also extend to information relating to matrimonial property, as far as the ECS is issued in a Member State participating in the enhanced cooperation and used in another participating Member State. A specific provision to that effect could have been included in the Matrimonial Property Regulation: it is regrettable that this opportunity has not been seized.

${ }_{17}$ See A. Bonomi, P. Wautelet: Le droit européen des successions..., Article 69, $\mathrm{n}^{\circ} 24$.

18 Opinion of A-G Szpunar, 13.12.2017, in case C-558/16, Mahnkopf, ECLI: EU:C:2017:965, para. 100 et seq.

${ }^{19}$ CJEU, 1.3.2018, Mahnkopf, case C-558/16, ECLI:EU:C:2018:138, para. 42 et seq.

${ }^{20}$ A. Bonomi, P. Wautelet: Le droit européen des successions..., Articles 68, $n^{\circ} 39$ et seq., $69, n^{\circ} 25$. 
Admittedly, such a provision could also be included, in the future, in the Succession Regulation, when this text will be reviewed. However, this will only happen after 2025, year when the Commission is required to submit a report on the application of that Regulation.

\section{c) The scope ratione materiae}

The Succession Regulation and the Matrimonial Property Regulations govern two areas of law, which are very closely connected. The determination of their respective scope is particularly important to prevent overlapping and gaps.

In principle, the dividing line between the two instruments is clear. Indeed, while the former excludes matrimonial property from its substantive scope (Article 1(2)(d) of the Succession Regulation), the latter in turn leaves out successions (Article 1(2)(d) of the Matrimonial Property Regulation). In concreto, however, the determination of the boundaries between the two instruments largely depends on the exact meaning of "succession", on the one hand, and "matrimonial property regime", on the other.

These notions are defined in the relevant instrument. Thus, under Article 3(1)(a) of the Succession Regulation, “'succession' means succession to the estate of a deceased person and covers all forms of transfer of assets, rights and obligations by reason of death, whether by way of a voluntary transfer under a disposition of property upon death or a transfer through intestate succession". And under Article 3(1)(a) of the Matrimonial Property regulation "matrimonial property regime' means a set of rules concerning the property relationships between the spouses and in their relations with third parties, as a result of marriage or its dissolution". Since these two areas of law are closely related and often intertwined, the distinction might prove difficult in several borderline cases, notwithstanding the definitions.

As is well known, when the Court of justice was confronted with this issue in the Mahnkopf case ${ }^{21}$, it opted for a broad understanding of the notion of "succession", as suggested by AG Szupnar in its opinion ${ }^{22}$. According to this interpretation, national rules belong to succession when "they deploy their effect in the case of succession" and "determine the

${ }^{21}$ CJEU, 1.3.2018, in case C-558/16, Mahnkopf, ECLI:EU:C:2018:138, in which the court ruled that a provision such as §1371(1) BGB "which prescribes, on the death of one of the spouses, a fixed allocation of the accrued gains by increasing the surviving spouse's share of the estate falls within the scope of that regulation."

${ }^{22}$ Opinion of A-G Szpunar, 13.12.2017, in case C-558/16, Mahnkopf, ECLI: EU:C:2017:965, para 93. 
rights of the surviving spouse in the relationship with the other heirs" ${ }^{23}$. A broad understanding of this notion had also been followed - albeit in a different context - in the Kubicka decision ${ }^{24}$.

While the result of their application in the Mahnkopf case is not exempt from criticism $^{25}$, the criteria provided by the Court can (and probably will) be used as a yardstick for other controversial characterisation issues. To take one example, we can mention dispositions included in a marriage contract in contemplation of the death of a spouse, as they are often used in France and other countries (so-called avantages matrimoniaux, e.g. a clause d'attribution intégrale au conjoint survivant). If we transpose the Mahnkopf criteria, it seems that such dispositions should be characterised as dispositions upon death (and more specifically as agreements as to succession, within the meaning of Article 3(1)(b) of the Succession Regulation) because "they deploy their effect in the case of succession" and "determine the rights of the surviving spouse in the relationship with the other heirs". Such characterisation would certainly deserve approval, because the effect of such clauses goes clearly beyond the scope and purposes of a matrimonial property regime.

As in the Mahnkopf case, such broad reading of the concept of succession would also help to extend the scope and efficacy of the ECS. Thus, the effects of the certificate would extend to the property transferred by way of avantages matrimoniaux, and this in all Member States that are bound by the Succession Regulation.

From the perspective of Poland and other non-participating Member States, this are probably good news: although such Member States are not bound by the Matrimonial Property Regulation, they can only benefit of a broad interpretation of the Succession Regulation. This will not only promote the effects of the ECS, but also extend the scope of application of the harmonised private international law rules included in that instrument.

${ }^{23}$ CJEU, 1.3.2018, in case C-558/16, Mahnkopf, ECLI:EU:C:2018:138, para 40.

${ }^{24}$ CJUE, 12.10.2017, in case C-218/16, Kubicka, ECLI:EU:C:2017:755.

25 Since $§ 1371(1)$ BGB is only applicable, as a matter of German law, when the spouses were subject to the default property regime of the "Zugewinngemeinschaft" ("equalisation of the accrued gains'), the assessment of the Court according to which that provision "does not appear to have as its main purpose the allocation of assets or liquidation of the matrimonial property regime" (CJEU, Mahnkopf, para. 40) is debatable. One should also consider that - while the Mahnkopf decision specifically concerned the effects of the European Certificate of Succession (see supra, section III(b)), its indirect implications on the determination of the applicable law might be odd: if $\S 1371(1)$ BGB is applicable when the succession is governed by German law (as it follows from its characterisation as pertaining to succession), would this also be the case when the matrimonial property falls under a foreign law? 


\section{The interaction between the Matrimonial Property Regulation and the Succession Regulation with respect to jurisdiction}

Because of their material proximity, the Matrimonial Property Regulation and the Succession Regulation are designed to interact in many respects. Such interaction has largely influenced the rules on jurisdiction of the Matrimonial Property Regulation.

Pursuant to Article 4 of this instrument, when the courts of a Member State are seized of a succession matter under the Succession Regulation, the jurisdiction of the court seized also extends to matrimonial property issues, provided that they are related to the succession.

The purpose of this provision is clearly to ensure a concentration of proceedings ${ }^{26}$. The court competent for ruling on the succession of a married person has often to rule also on the matrimonial property regime. Indeed, the only property forming part of the estate in succession is that property which does not pass to the surviving spouse under the matrimonial property regime. In order for litigants to avoid delays or other unnecessary complications, it is important that the authority seized in relation to the succession can equally rule on claims based on the matrimonial relations. Such extension also avoids a situation in which the courts of different Member States may claim concurrent jurisdiction on such closely related issues. This clearly serves the interests of procedural economy and efficiency, since it is expedient, on grounds of both procedural costs and convenience for the parties, to combine closely related proceedings.

However, concentration of proceedings is not guaranteed in an absolute manner by the Matrimonial Property Regulation. Given that this instrument regulates neither jurisdiction with regard to the subject matter (cf. Article 2), nor the territorial jurisdiction of the court on a domestic level, Article 4 does not attribute jurisdiction to the court seized, but rather to the courts of the same Member State. It is thus possible that within a Member State, the court competent to address issues regarding the matrimonial property regime may not be the same as the courts

${ }^{26}$ See Recital 32. See P. Mankowski: Internationale Zuständigkeit nach EuGüVO und EuPartVO. In: Die Europäischen Güterrechtsverordnungen. Eds. A. Dutta, J. Weber. Beck, 2017, p. 13, n 2; P. Franzina: Jurisdiction in Matters Relating to Property Regimes under EU Private International Law. "YPIL”, 2017/2018, p. 163. 
seized for determining succession issues ${ }^{27}$. Despite this, a certain concentration is nevertheless ensured, because the courts of the same Member State can rule both on matters of succession as well as on matrimonial property.

The coordination between the two instruments brought about by Article 4 goes in certain cases even too far, at the expenses of other important objectives, such as proximity and predictability ${ }^{28}$.

Indeed, the "derived" jurisdiction under Article 4 is to be interpreted broadly. It is provided not only for the most common case, when the jurisdiction in succession matters is based on the last habitual residence of the deceased (Article 4 of the Succession Regulation), but also when it results from other provisions of the Succession Regulation (Articles 5 to $11{ }^{29}$. In the former case, the provision leads to fair results, because the courts of the Member State of the last habitual residence of the deceased spouse are generally well placed to also rule on the property rights arising from the marriage. By contrast, this is not always the case when the jurisdiction for succession matters is based on other subsidiary rules of the Succession Regulation, in particular on Article 10.

As is well known, the jurisdictional reach of Member States courts under Article 10 of the Succession Regulation is very broad, sometimes even extensively so. Based on the location of assets in a Member State and on the nationality or a previous habitual residence of the deceased, the courts of that Member State are granted by Article 10(1) all-inclusive jurisdiction for the whole of the estate, including assets situated abroad ${ }^{30}$. Already somewhat questionable in matters of succession, this wide jurisdiction also extends, by virtue of Article 4 of the Matrimonial Property Regulation, to matrimonial property, and it encompasses potentially all assets belonging to the spouses. This is very far-reaching: indeed, it is difficult to understand why the courts of the jurisdiction of the State where a part of the property of the deceased spouse is situated (note that it can also be his or her personal property) should have jurisdiction to rule on the sharing out of the matrimonial property regime, including the property of the spouses which is situated abroad. The too extensive

${ }^{27}$ See P. Mankowski: Internationale Zuständigkeit..., p. 14, n 3, et p. 15, n 5 .

${ }^{28}$ See A. Bonomi: Compétence accessoire versus proximité et prévisibilité du for : quelques réflexions sur ces objectifs antagonistes à l'aune des Règlements sur les régimes et les partenariats. In: Melanges en l honneur du professeur bertrand ancel. Iprolex, 2018, p. 232.

${ }^{29}$ See P. Mankowski: Internationale Zuständigkeit..., n 4, p. 15; P. Franzina: Jurisdiction in Matters Relating to Property..., p. 166 s.

${ }^{30}$ A. Bonomi, P. Wautelet: Le droit européen des successions..., Article 10, n 14 ss et $19 \mathrm{ss}$. 
scope of this jurisdictional rule is even more apparent in the scenario, seen frequently in practice, in which the spouses, at the moment of death, were living together in the same non-Member State. In this scenario, the authorities of the State of the common habitual residence will generally have jurisdiction to rule, at the same time, on the succession and on the distribution of the matrimonial property. They are also best placed to do so for reasons of proximity and predictability. Conferring all-inclusive jurisdiction on the courts of the Member State of the place in which a part of their property is situated is necessarily designed to create a positive conflict with the authorities of the third State of the habitual residence.

An example will clarify the criticism. Let us assume that a German citizen dies in Switzerland, where he has his domicile and habitual residence with his Swiss wife. He left property in Germany which he inherited from his parents. Based on their national PIL rules, Swiss courts will have jurisdiction to rule on the succession and on the matrimonial property $^{31}$. Nevertheless, based on Article 10(1) of the Succession Regulation, German courts will have concurrent jurisdiction to rule on the entire estate, including property situated in Switzerland. As an effect of Article 4 of the Matrimonial Property Regulation, their jurisdiction extends also to issues of matrimonial property, without any limitation. This is the case even if the surviving spouse never had any relationship to Germany.

Of course, the court seized on the basis of Article 10(1) might rely on Article 12 of the Succession Regulation and on the analogous provision of Article 13 of the Matrimonial Property Regulation in order to exclude from the proceedings certain assets located abroad (in our example property situated in Switzerland), but these provisions are discretionary and subject to conditions.

Such excessive, and probably unintended, side-effects of the coordination between the two Regulations could have been prevented if the European lawmaker had been more cautious. Article 5 of the Matrimonial Property Regulation offers a good example: while the first paragraph of that provision mirrors Article 4 providing for similar coordination mechanism ("derived" jurisdiction of the courts seized under the Brussels IIbis Regulation), its second paragraph limits it by requiring both spouses' agreement when the divorce proceedings have been initiated in a "weak" forum ${ }^{32}$. A similar restriction should have been provided in Article 4.

The impact of Article 4 of the Matrimonial Property Regulation

${ }^{31}$ Articles 51(a) and 86(1) of the Swiss PIL Act.

${ }^{32}$ This applies in particular to jurisdiction based on the habitual residence of the plaintiff under Article 3(1) of the Brussels IIbis Regulation and to "residual jurisdiction" as provided by the law of the forum under Article 7 of that Regulation. 
in connection with Article 10 of the Succession Regulation is very farreaching not only in the relationship with a non-Member State (such as Switzerland), but also in the relationship with those Member States, which are not bound by the Succession Regulation (Denmark and Ireland). By contrast, one should distinguish in this respect the position of those Member States that are party to the Succession Regulation, such as Poland.

If we assume, in the foregoing example, that the deceased's last habitual residence was in Poland, Polish courts will have jurisdiction over the succession based on Article 4 of the Succession Regulation. As a consequence, the courts of other Member States (in our example, German courts) will not be able to take jurisdiction under Article 10 of the same Regulation and, therefore, they will also be prevented from relying on Article 4 of the Matrimonial Property Regulation. Admittedly, this does not completely rule out the possibility of concurrent jurisdiction: indeed, the jurisdiction of a Member State's court over matrimonial property could still be based on Articles 6, 10 or 11 of the Matrimonial Property Regulation. However, since these rules are less far-reaching than Article 10 of the Succession Regulation, the potential for conflicts is more limited.

\section{The interaction between the Matrimonial Property Regulation and the Succession Regulation with respect to the applicable law}

A good coordination between the Succession Regulation and the Matrimonial Property Regulation is extremely important also with respect to the applicable law. Indeed, complex characterisation issues, such as those dealt with in the Mahnkopf case, can be avoided if the same substantive law is applicable to both succession and matrimonial property; adaptation problems can also be prevented this way ${ }^{33}$.

However, the EU lawmaker was not impressed by these arguments and decided, in the field of applicable law, to prioritise other goals, in particular a certain (not entirely convincing) idea of predictability of the applicable law. The result is that, in many instances, the law applica-

${ }^{33}$ A. Bonomi: The Interaction Among the Future EU Instruments on Matrimonial Property, Registered Partnerships and Successions. "YPIL", 2011, Vol. XIII, p. 219 et seq. 
ble to matrimonial property under the Matrimonial Property Regulation will differ from the law applicable to the succession under the Succession Regulation.

Indeed, while the Succession Regulation designates the law of the last habitual residence of the deceased (Article 21(1)), the main connecting factor of the Matrimonial Property Regulation points to the law of the first common habitual residence of the spouses after (or better "short after" ${ }^{34}$ ) the marriage (Article 26(1)(a)).

It follows that the same law will generally be applicable to succession and matrimonial property when the spouses did not change their habitual residence during the marriage. The same is true if the spouses, after having lived in different countries during the marriage, return in the end to the country where they had established their first habitual residence after the marriage.

By contrast, two different laws will govern matrimonial property and succession whenever at the moment of the death of one of the spouses, his or her habitual residence was situated in a country other than that of the first habitual residence after the marriage, that is, in most of the cases where the spouses have changed their common habitual residence during their marriage.

Let us take the case of a couple formed by an English wife and a German husband, who marry in England and establish in that country their first common habitual residence: their matrimonial property is governed by English law. In principle, this will not change when the spouses move to Germany some years after the marriage. However, when years after the husband dies, German law will be applicable to his succession as the law of his last habitual residence. The German courts having jurisdiction for both succession and the sharing of the matrimonial property, will have to apply German law to the former and English law to the latter, which can raise some difficult issues.

A better coordination between the two related matters could be brought about through the so-called escape clause of Article 26(3) of the Matrimonial Property Regulation. This provision allows the court, by way of exception and on request of one of the spouses, to apply the law of the spouses' last common habitual residence in lieu of the law of their first common habitual residence after the marriage. However, this pro-

${ }^{34}$ See Recital 49. The philosophy of the Regulation, which is based on the principle of "immutability" of the applicable law, implies that in the absence of a common habitual residence established "shortly after" the marriage, the subsidiary connecting factors (common nationality, closest connection) become applicable: see D. Coester-Waltjen: Connecting Factors..., p. 203; B. Heiderhoff: Die EU-Güterverordnungen. "IPRax", 2018., p. 5. 
vision is subject to two cumulative conditions: it is required a) that the duration of their last habitual residence was significantly longer than their first habitual residence, and b) that both spouses relied on that law in arranging or planning their property relations. It is also important to stress, that even if these conditions are satisfied, the escape clause does not operate de iure, but it depends on a discretional decision of the court. Subject to these conditions, this provision can prove a useful coordination tool in order to ensure that the same law is applicable to both matrimonial property and succession.

However, the exception clause is not applicable ${ }^{35}$ when, in the absence of a habitual residence of the spouses at the moment of the marriage or shortly thereafter ${ }^{36}$, matrimonial property is governed by the law of the common nationality of the spouses or, failing it, by the law of the country to which the situation is most closely connected (Article 26(1)(b) and (c)). Such subsidiary connecting factors can also frequently lead to the application of a law other than that of the last habitual residence of the deceased, governing the succession, even more so, because they both refer to the time of the marriage. Since subsequent circumstances, including the last habitual residence of the spouses, are completely irrelevant in these cases, it will be impossible for the court to correct this result by submitting the two related matters to a single law.

A better coordination could often be achieved by the spouses through the choice of the applicable law. In particular, in the case of change of their habitual residence, they can submit their matrimonial property relations to the law of their new habitual residence, which will also probably be the law eventually applicable to their succession. If they provide their choice with a retroactive effect, one single law will apply to all these issues ${ }^{37}$. Thus, in the foregoing example, the English wife and her German husband - after moving to Germany - could have designated German law as the law of their new common habitual residence to govern their property relations; they could have also provided their choice with a retroactive effect. This way, they would have ensured that German law would be applicable to all issues relating to the matrimonial property and the succession.

${ }_{35}$ This objectionable limitation results from the black-letter text of Article 26(3): "[...] the judicial authority having jurisdiction to rule on matters of the matrimonial property regime may decide that the law of a State other than the State whose law is applicable pursuant to point (a) of paragraph 1 shall govern the matrimonial property regime [...]" (emphasis added). See the criticism by B. Heiderhoff: Die EU-Güterverordnungen..., p. 6; D. Coester-Waltjen: Connecting Factors..., p. 207.

${ }^{36}$ See supra, fn. 32.

${ }^{37}$ In the absence of a specific indication by the spouses, the law chosen during the marriage will only be applicable prospectively: see Article 22(2) of the Regulation. This will result in two different laws subsequently applicable to the matrimonial property. 
We now turn to the impact of these rules from the perspective of a non-participating Member States, such as Poland.

Obviously, non-participating Member States, as well as non-Member States, will not apply the conflict of laws rules of the Matrimonial Property Regulation, but will determine the law applicable to matrimonial property under their own, national conflict of laws rules.

In the case of Poland, these will point first to the law of the spouses' current common nationality (Article 51(1) of the Polish PIL Act). In international cases, this law will frequently be different from the law governing the succession under the Succession Regulation. Moreover, it will also frequently be different from the law of the first habitual residence of the spouses, applicable to matrimonial property in the Member States bound by the Matrimonial Property Regulation.

Let us assume that a couple of Lithuanian citizens marry in Germany, where they establish their first common habitual residence. Some years after the marriage, they move to Poland, where the husband eventually dies. Polish court will have jurisdiction to rule on the succession under the Succession Regulation and will apply Polish law to the succession; however, they will have to apply Lithuanian law to the matrimonial property (Article 51(1) of the Polish PIL Act). If we assume that the couple owned immovable property in Germany, German courts will also have jurisdiction to rule on those assets under Article 10 of the Matrimonial Property Regulation and they will apply German law to this issue (Article 26(1)(a) of the Matrimonial Property Regulation). As a result, there is no coordination between succession and matrimonial property, and no coordination between participating and non-participating Member States.

In the absence of a common nationality, the Polish PIL Act submits matrimonial property to the law of the spouses' common domicile (or failing it, of their common habitual residence). Although Article 51(2) of the Polish PIL Act does not expressly state it, it is intended to refer - as Article 51(1) for the case of common nationality - to the law of the current domicile (or the current habitual residence) of the spouses. Therefore, if we assume, in our previous example, that the English-German couple, after living in England and in Germany, had eventually moved to Poland, Polish law would become applicable to their matrimonial property. In case of death of one of them, Polish law would be also applicable to the succession. However, if the spouses also owned immovable property in Germany, German courts also have jurisdiction to rule on these assets under Article 10 of the Matrimonial Property Regulation, and would apply English law as the law of the first habitual residence of the spouses, subject to the exception clause. 
As this example shows, Polish law - based on the mutability principle - sometimes grants a better coordination between matrimonial property and succession. By contrast, the law governing matrimonial property will often be in contradiction with the law applicable in the participating Member States. This can lead to conflict if one of these States has concurrent jurisdiction, as it is the case with respect to immovable property located there (Article 10 of the Matrimonial Property Regulation).

\section{Lack of coordination between participating Member States and third States with respect to parallel proceedings and recognition of decisions}

Concurrent jurisdiction together with diverging choice-of-law rules can lead to positive conflicts. These can sometimes be prevented through the application of lis pendens rules or through the recognition of foreign judgments.

As the Succession Regulation, the Matrimonial Property Regulation includes both rules on lis pendens and related actions (Articles 17 and 18), and rules on recognition and enforcement of decisions (Chapter IV). However, these rules are only applicable in the relationships among the participating $\mathrm{MS}^{38}$.

Contrary to the Brussels Ibis Regulation ${ }^{39}$, the Matrimonial Property Regulation - as already the Succession Regulation and all other regulations in the field of family law - does not include specific rules on lis pendens and related actions applicable in the relationship to third States. This gap might be filled by national lis pendens rules provided that such rules actually exist in the States concerned, and that they are considered to be compatible with the European harmonised rules on jurisdiction a question that arose after the Owusu judgment by the Court of Justice of the European Union, and that is still unresolved ${ }^{40}$.

38 See supra, section II.

39 Articles 33 and 34 of the Brussel Ibis Regulation.

40 By holding that Article 2 of the Brussels Convention is "mandatory in nature" and that "there can be no derogation from the principle it lays down except in the cases expressly provided for by the Convention" (CJEU, 1 May 2005, Owusu, in case C-281/02, ECLI:EU:C:2005:120, para. 37), the CJEU has cast a doubt on the compatibility of national lis pendens rules with the jurisdictional rules included in EU law instruments. 
Similar considerations apply, mutatis mutandis, with respect to recognition and enforcement of decisions. So far, no European regulation includes rules on recognition and enforcement of third States' decisions an issue that was only discussed in academic circles and addressed in an interesting resolution adopted by the EGPIL ${ }^{41}$. Therefore, recognition and enforcement of such decisions is still left to the national recognition rules of the participating Member States. Several of these States are quite open to recognition of third State judgments in the area of matrimonial property, but this is not necessarily the case of all of them.

Nevertheless, a decision rendered in matters of succession is entitled to recognition and enforcement under the Succession Regulation in all Member States bound by this instrument. This holds true even if that decision rests on a decision on the sharing out of matrimonial property, which does not benefit from recognition rules of the Matrimonial Property Regulation and cannot be recognised under the national recognition rules.

\section{References}

Bonomi A.: The Interaction Among the Future EU Instruments on Matrimonial Property, Registered Partnerships and Successions. "YPIL", 2011, Vol XIII.

Bonomi A.: Explanatory Report on the Hague Protocol of 23 November 2007 on the Law Applicable to Maintenance Obligations, The Hague 2009

Bonomi A.: Compétence accessoire versus proximité et prévisibilité du for: quelques réflexions sur ces objectifs antagonistes à l'aune des Règlements sur les régimes et les partenariats. In: Melanges en l honneur du professeur bertrand ancel. Iprolex, 2018.

Bonomi A., Wautelet P.: Le droit européen des successions: commentaire du

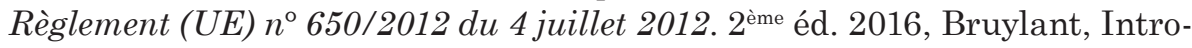
duction, $\mathrm{n}^{\circ} 16$.

Calvo Caravaca A.-L., Davì, H.-P. Mansel A.: The EU Succession Regulation. Cambridge, 2016, $\mathrm{n}^{\circ} 13$, p. 17 et s.

Coester-Waltjen D.: Connecting Factors to Determine the Law Applicable to Matrimonial Property Regimes. "YPIL", 2017/2018.

Corneloup S. (éd.): Droit européen du divorce. Paris 2013.

${ }^{41}$ The European Group of PIL thoroughly analysed the question of uniform rules for third-country judgments in its Copenhagen and Brussels meetings and came up with a detailed draft proposal, available at http://www.gedip-egpil.eu/documents/gedip-docu ments-20poe.htm (accessed 31.08.2020). 
Dutta A.: Beyond Husband and Wife - New Couple Regimes and the European Matrimonial Property Regulations. "YPIL", 2017/2018.

Dutta A., Weber J. (éds.): Die Europäischen Güterrechtsverordnungen. Beck, 2017.

Franzina P.: Jurisdiction in Matters Relating to Property Regimes under EU Private International Law. "YPIL", 2017/2018.

Hammje P.: 'Mariage pour tous' et droit international privé. "Rev. crit. DIP", 2013.

Heiderhoff B.: Die EU-Güterverordnungen. "IPRax", 2018.

Magnus U., Mankowski P.: Brussels IIbis Regulation. Munich 2012, Art. 1er $\mathrm{n}^{\circ} 21$.

Rauscher Th.: EuZPR-EuIPR Europäisches Zivilprozess- und Kollisionsrecht-Kommentar, vol. IV, Art. 1 Brüssel IIa-VO, nº 6 à 8. 